\title{
Proceedings Rieport
}

\section{White Pa|per on Scieñe.}

Technology and Dnnovation (STI)

$$
\text { } 2 \text { as } P \text { art of the }
$$

Incilusive Development (IID)

\section{seminar Series}

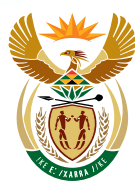

science \& innovation

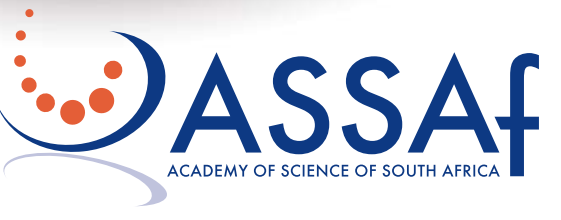


Oc tober 2019

ISBN 978-1-928496-20-5

DOI http://dx.doi.org/10.17159/assaf.2019/0055

Cite:

Academy of Science of South Africa/Department of Science and Innovation, (2019). Stakeholders Awa reness Workshop on the 2019 White Paper on Science, Technology and Innovation (ST)

DOI 10.17159/a ssaf.2019/0055

Published by:

Aca demy of Science of South Afric a (ASSAf)

PO Box 72135, Lynnwood Ridge, Pretoria, So uth Afric a, 0040

Tel: +27 $123496600 \cdot$ Fax: +27865769520

E-mail: admin@assaf.org.za

Department of Science and Innovation (DSI)

DSI Building (Building no. 53), CSIR Campus (South Gate

Entrance), Meiring Naudé Road, Brummeria, Pretoria

Tel: +27 128436300

The Academy of Science of So uth Africa (ASSAf) was inaugurated in May 1996. It was formed in response to the need for an Academy of Science consonant with the dawn of democracy in So uth A fric a : activist in its mission of using science and sc holarship for the benefit of society, with a mandate encompassing all scholarly disciplines that use an open-minded and evidence-based approach to build knowledge. ASSAf thus, adopted in its name the term 'science' in the singular a sreflecting a common way of enquiring rather than an aggregation of different disciplines. Its Members are elected based on a combination of two principal criteria, a cademic excellence and signific ant contributions to soc iety.

The Parliament of South Africa passed the Academy of Science of South Africa Act (No 67 of 2001), which came into force on 15 May 2002. This made ASSAf the only aca demy of science in South Afric a offic ially recognised by govemment and representing the country in the intemational community of science academies and elsewhere.

This report reflects the proceedings of the Stakeholders Awareness Workshop on the 2019 White Paper on Science, Technology and Innovation (ST) as part of the Innovation for Inclusive Development (IID) Seminar Series held at Future Africa. Views expressed are those of the individuals and not necessarily those of the Academy nor a consensus view of the Academy based on an in-depth evidence-based study.

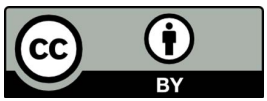


NII 


\section{TABIE OF CONTENTS}

\section{ACKNOWFDGEMENTS}

WELCOME AND INTRODUCTION

(Mr Imraan Patel, Deputy Director General: Socio-Economic Innovation Partnerships, Department of Science and Innovation, DSI)

WHITE PAPER ON SCIENCE AND TECHNOLOGY 2019

(Ms Urszula Rust, Senior Policy Specialist, Department of

Science and Innovation, DSI)

DISC USSION: QUESIIONS/ COMMENTS

INNOVATION FOR INCLUSIVE DEVELOPMENTSTRATEGY

(Ms Nonhlanhla Mkhize, Chief Direc tor: Innovation for Inc lusive Development, Department of Science and Innovation, DSI)

DISC USSION: QUESIIONS/ COMMENTS

\section{BREAK-AWAY SESSIONS}

Chair: MrEphraim Phala fa la, Deputy Direc tor: S\&Tfor Susta ina ble Human Settlements, Department of Sc ience and Innovation, DSI

Presenter: Ms Nonhla nhla Mkhize, Chief Direc tor. Innovation for Inc lusive Development, Depatment of Science and Innovation, DSI 


\section{TABILOF CONTENTS (CONT.)}

\section{SESSON 2: INNOVATION FOR LOCALECONOMIC} DEVEOPMENT(ILED)

Chair: Mr Eric Watkinson, Department of Science and Innovation, DSI

Presenter: Ms Busisiwe Ntuli, Direc tor: Tec hnology for Susta ina ble Livelihoods, Department of Science and Innovation, DSI

DISC USSION: QUESTIONS/ COMMENIS

REPORT BACK RROM BREAK-AWAY SESSIONS 


\section{ACKNOWIEGEMENTS}

This proceedings report is a product of the Academy of Science of South Africa (ASSAf) in partnership with the Department of Science and Innovation (DSI) on the Innovation for Inclusive Development (IID) seminars. The IID leaming interventions align with one of DSl's strategic objectives, namely, to use "knowledge, evidence and lea ming to inform and influence how science and technology may be used to achieve inclusive development". The purpose is to demonstrate how innovative technology solutions may be used to improve the capacity of the State to deliver and improve access to basic services, and thereby advance localeconomic development.

The seminar entitled "Stakeholders Awareness Workshop on the 2019 White Paper on Science, Technology and Innovation (ST)" provided an opportunity for stakeholders to reflect on the policy intents of the cabinet a pproved 2019 White Paperon Science, Technology and Innovation (ST). The White Paper sets a long-term policy direction for the South African Govemment to ensure the growing role for the $5 \pi$, which is aligned to the developmental challenges of the country. The paper is based on the extensive review of the National System of Innovation (NSI) and foc uses on using ST to accelerate inclusive economic growth and to assist South Africa to benefit from global development such as rapid technological advancements, geo-political and demographic shifts. The new White Paper seeks to ensure that South Africa benefits from the potential of ST to advance the objectives of the National Development Plan (NDP) by instilling a culture of va luing ST, expansion and transformation of research systems, institutional landscape and human resource base of the ST, increased funding and funding efficiencies etc. The outcomes of the seminar will feed into the DSl's Decadal Plan to direct the implementation plan for the 2019 White Paper on ST.

ASSAf acknowledges the DSI and all the speakers. The 130 participants from various sectors including the public and private sector, nongovemmental organisation (NGOs), academia and media are greatly acknowledged individually and collectively. 
The contributions of the ASSAf Liaison Programme, led by Mr Stanley Maphosa and the contact person for this project Dr Tebogo Mabotha's contributions throughout the project are hereby acknowledged and appreciated.

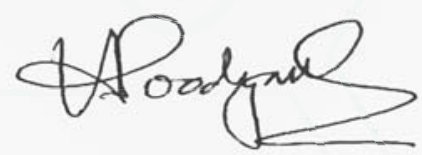

\section{Prof Himla Soodyall} ASSAf Exec utive Offic er 


\section{WELCOMEAND INTRODUCTION}

\section{Mr Imraan Patel, Deputy Director General: Socio-Economic Innovation Partnerships, Department of Science and Innovation, DSI}

MrPatel set the tone for the deliberations by reflecting on the following:

- The debate about the Smart cities concept was raised in President Rama phosa'srecent State of the Nation Address(SONA). The President called for a discussion on how to reimagine Sustainable Human Settlements (SHS), and in this context, input from this seminar would be welcomed. Those in STl could help contribute to this discussion, for example by considering possible small-scale pilot projects and leveraging from what already exists in this space.

Mr Patel anticipated that the discussions at this workshop would highlight STI's a mbition, drive and support for the Sma rt cities concept within the space created through the White Paper on STl, as well as short- and longer-term measures for implementation.

- Increasingly, a very strong narra tive a round partnershipshasemerged in political discourse in recent years. This was one of the key points in the Minister's foreword to the White Paper on STl and came across strongly in the SONA and many of the responses from other Ministers. The coordination question has not yet been fully resolved. The White Papercorrec tly identified that coordination is a series of things and has to do with institutions as well as mindset. This called for deep reflection as well as a process of iteration and finding appropriate institutional models. Much was happening in this space, yet the mechanisms for ongoing systematic coordination have not been determined.

Mr Patel appealed to participants to be open to listening to what others were doing and find the connec tions between different spaces in order to identify high impact projects or initia tives.

- The issue of inclusive development required a more deliberate approach. This called for continuous analysis so as to be able to intemalise key stakeholders groupings and ensure inclusion of communities outside of the STI sector. Inclusion had to do not only 
with what was in the White Paper, but also about leaming to do transformation in terms of partnerships to ensure inclusion.

Mr Patel requested that the words 'transformation, innovation and partnerships' in the Minister's foreword to the White Paper should serve as a backdrop to the discussions.

Outcomes of this workshop would feed into the DSl's Decadal Plan, serving as drivers for future plans and partnerships.

\section{WHITE PAPER ONSCIENCEAND TECHNOLOGY2019}

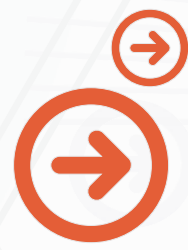

\section{Ms Urszula Rust, Senior Policy Specialist, Department of Science and Innovation, DSI}

MsRust's presentation provided a high-level overview of the White Paper to set the scene for the group disc ussions.

Despite substantial progress made by the DSI and STl-intensive departments, the National System of Innovation (NSI) has not fully lived up to its potential in supporting the country's economic growth and development challenges. This, together with the changes in megatrends and global technologies, highlighted the need to update ST policy. The 2019 White Paper on STl was a pproved on 13 March 2019 and its vision is stated as 'STl enabling inclusive sustainable South African development in a changing world'.

The White Paper'sobjectives are to:

- Instil a culture of valuing STI

- Create an enabling and inclusive NSI govemance environment

- Facilitate innovation

- Increase and tranform the human resource base of the NSI 
- Expand and transform the research system

- Expand the institutional landscape

- Increase funding and funding efficiencies.

Some examples of the policy intents in the White Paper relating to the objectives are:

- Creating and enabling and inc lusive NSI govema nce environment, achieved through:

- An Annual ST Plenary chaired by the Presidency, that would bring together business, c ivil so ciety, academia and govemment to disc uss NSI needs and progress

- A Ministerial ST Structure that would adopt an Innovation Compact that would drive coordination across govemment

- Bolstering the National Advisory Council on Innovation (NACI) to support the Ministerial ST Structure and undertake monitoring and evaluation (M\&E) for the NSI

o Using Intellectual Property (IP) from public ly funded research and development (R\&D) to help transform the ownership of the economy

- Institutiona lising a gender framework

- Revita lising critic al ST policy nexuses (on the economy, on education, and on social issues)

- Improving sector coordination via Sector STI Pla ns, fully involving business

o Empowering the role of civil society in innovation.

- Innovation would be enabled and facilitated through:

o Strengthening the innovation culture

- Adopting a govemment Innovation Compact a ligning STI a nd polic ies of other govemment departments

- Encoding sovereign innovation priorities in Decadal Plans to focus effort and resources

o Harmonising innovation incentives to inc rease access for innovators

- Broadening policy focus on innovation beyond R\&D and include loc a lisation 
- Increasing provincial and local level innovation

- Supporting grassroots and social innovators

o Strengthening Offic es of Technology Tranfer

o Providing increased support for business

- Improving the integration of innovators into global value chains

- Adopting locally developed technologies

- Tapping new sources of growth (such as Circ ular/green economy, the next industrial revolution).

- The human resource base of the NSI would be increased and transfomed through:

- Building a science-a ware soc iety by tra ining science jouma lists and expanding the network of science centres (with support from business) for example

o Increasing the Science, Technology, Engineering, Mathematics (STEM) pipeline, developing more technical skills, providing more training abroad and retaining researchers in the higher education system.

o Strengthening intemational collaboration and science diplomacy, especially in Africa.

- Expanding and transfoming (in the wider sense) the research system through:

o Utilising the potential of the historic a lly Black universities a nd Universities of Tec hnology, as well as the 'silent majority'" (lecturers who do very little, if any, research)

o Institutionalising a research prioritisation process (while ensuring that there is room for curiosity- based research) in order to be able to fund certain initia tives at critical mass

o Funding prionity research a reas better.

- Increa sing support for research (basic, inter- and tra nsd isciplinary, Social Sciences and Humanities)

o Supporting a culture of openness, as and where appropriate

o Increasing investment in infrastruc ture, including cyber infrastructure.

- Increa sing funding and funding effic iencies through: 
- Targeting Gross Expenditure on R\&D (GERD) of $1.5 \%$ of G ross Domestic Product (GDP) in the next ten years

- Establishing a Sovereign Innovation Fund

- Exploring untapped funding sources (such as corporate social investment, crowd funding)

- National departments setting a side an appropriate \% of budgets for ST

o Increasing investment in incubators and grassroots entrepreneurs by provincial and local departments.

o Promoting STl-focused Foreign Direct Investment (FDI) and targeting multinational corporations.

- More support from development fina nce institutions for STl-d riven ind ustria lisa tion

o Harmonising funding instruments and improving their efficiency.

o Improving the allocation of resources through an STl public budget coordination process that interfaces with the Department of Planning, Monitoring and Evaluation (DPME) Budget Mandate Paperand the National Treasury processes.

There has been a major shift from the 1996 to the 2019 White Papers in several areas. The overarching shift concems the 1996 White Paper's foc us on developing and building the NSI, whereas the 2019 White Paper foc ussed on increa sing the impact of STI on the country' seconomic and developmental prionities, The 2019 White Paper broadens the Science and Technology (S\&T) focus to include innovation, addresses crosscutting partnerships and sectoral STl plans and budgets, and reflects the move towards openness and the 4th Industrial Revolution (4IR).

The DSI recently began working on a Decadal Plan that would direct the implementation plan for the White Paperand guide research, technology and innovation focus areas for the NSI over the next decade. It would be a collaborative document, developed with input from govemment as well as business, academia and civil society. Documents that would provide input to the Decadal Plan include the White Paper on ST, the $\mathrm{NACl}$ foresight study, the NACI review of the National Research and Development Strategy and the Ten-Year Innovation Plan, and the National Development Plan (NDP). 


\section{DISC USSION: QUESTIONS/COMMENTS}

(Question) Prof. Kobus Eloff, University of Pretoria (UP): I a m very enc ouraged with the 2019 White Paper. However, successneed sto be supported and excellence needs to be rewarded. This is missing. White males and top universitiesc an do a lot in thisa rea. Historic ally Bla ck universities should be supported by building collaborations. A lot of good work with a lot of ec onomic potential is going on at universities, but there is a gap between the research and commercialising innovation.

(Response) Ms Urszula Rust, DSI: The point about rewarding research excellence is valid. In the disc ussions a round the White Paper, building linkages between established research-ers and emerging researchers, retention of established researchers of whatever race and gender, and the need for incentives for established researchers to monitor and develop young people in the system were addressed. The issue is at the forefront of the thinking, but more deliberation on how best to do this is necessary. Through the Decadal Plan process, it will be possible to come up with particular programmes that can be measured.

(Comment) Mr Mmakgabo Maheya, South African Bureau of Standards (SABS): Innovation and technology a re an integral part of development, modemisation and commercialisation. For this reason, the Department of Trade and Industry (the dti) commissioned a study on technology commercialisation. Govemment departments and the different sectors are working in silos and their different polic ies continue to be a cause of frustration. SABS established a committee on innovation management three years ago. Prior to that, the DSI was regarded as the custodian of innovation in the country. The committee is involved with in global discussions and has developed a document on idea management, strategic intelligence management and IP management. Rewarding excellence is outlined in idea management. Forums such as this should involve all the role players.

(Response) Ms Urszula Rus, DSI: It is true that we continue to work in silos, but all the important actors need to be brought on board and decide to gether how best to counter this. We need to understand entrenched agendas that make it diffic ult forpeople to work together. There might be a storming, forming and noming phase as these forums a re brought into a policy lea ming space where we find out what others have been doing, what has worked and which lessonscan be leamt. This is one of the polic $y$ intents in the White Paper. 
(Question) Mr Sobuza Mathebula, Sol Plaatie Municipality: What are the different pha ses of developing DSI's Decadal Plan?

(Response) Ms Urszula Rus, DS: The Decadal Plan will be based on the White Paper, the NDP, the NACI foresight study and reviews, a swell as the plans of the new administration. The DSI is at the stage of looking at these documents and trying to define possible focus areas. These areas will be mapped to identify who owns the area, the progress that has happened in that area and so on. The next step is to have sector specific workshops to develop the content of the plan and once approved, there will be a public consultation process. The processshould take a yearor so. People will be brought into the process at the appropriate times and inputs are welcome.

\section{COMMENT:}

From the presentation, there is a huge need for people doing work a round the coordination of the NSI both at the high level and around the emphasis on science for transformation. I noted the comments on IP and the need to broker IP more productively into the economy. It iseven more diffic ult if we do not have tec hnolog ies and it is around knowledge that is in people's minds as this kind of science impacts processes around trust in people. We need to find ways in the Decal Plan to prioritise the funding it takesto have these 'silent coordinators' at different levels within the system and look at the $M \& E$ indic tors for this kind of work, rather than just foc ussing on the science outputs.

(Response) Ms Urszula Rust, DS: This is an insightful point. The White Paper ta lks a bout coordination not only in tems of committees, but a lso around values and setting up STl units in relevant places to start instilling an innovation mindset into work. $A M \& E$ and policy leaming framework, build ing the knowledge-policy interface, isgoing to be developed. These are the kinds of interventions to be considered.

\section{COMMENT}

So uth Afric a doesvery well in terms of $R \& D$ but isstifled when it comes to implementation. When dealing with policy makers, scientists and 
innovators need to be very clear about how they can assist them using existing tools. We cannot afford scientific ideas to be stifled and budgets exceeded but still not being at the implementation stage.

(Response) Ms Urszula Rust, DS: This is about who to bring on board at what stage. It will be difficult to bring policymakers on board too late. The issue is about how to support commercialisation and make sure, even at the sectoral level, that the initiatives work together. We need to come up with 'operating procedures' for these kinds of projects. It is hugely frustrating for scientists, once they have done a lot of good work, to try to find somebody to take the work forward. We will need to do this differently and will need guidance from the people at universities who actually do the work, about what they need to make this work and the kind of frameworks that need to be put in place.

(Comment) Mr Grant Greyling, The Innovation Hub: Please share more details a bout the Sovereign Innovation Fund.

(Response) MrImraan Patel, DS: The concept of the Sovereign Innovation Fund has been accepted. At the time this was being discussed it was combined with the gaps that the Department of Small Business Development had identified. There wasa jo int input to National Trea sury to conceptualise the fund. The work has not been fully developed because the requirementsfarexceed what is a va ila ble. Nevertheless, work is being done and as the new administration comes into play, final decisions will be made on how to take it forward. The idea of the fund is to create a targeted instrument that addresses the gap between good ideas and commercialisation. The rules still have to be developed. 


\section{INNOVATIONFOR INCLUSIVE DEVELOPMENTSTRATEGY}

\section{Ms Nonhlanhla Mkhize, Chief Direc tor: Innovation for Inc lusive Development, Department of Science and Innovation, DSI}

The workshop provided an opportunity to reflect on the policy intents of the 2019 White Paper and ensure the incorporation of stakeholder interventionsand initia tives in the DecadalPlan, being mindful ofemerging and converging tec hnologies and their influence on the quality of life.

The 1996 White Paper committed to hamessing S\&Tfor economic growth as well as improving quality of life for all. In around 2002, the National Research and Development Strategy introduced the Technology for Poverty Reduction Mission focussing on hamessing S\&T to develop technology solutions for improved access to basic services and capacity of the state to deliver those services, and to ensure an inclusive and accessible NSI. The Technology for Poverty Reduction Mission was implemented through sustainable livelihoods (or innovation for local economic development (LED)) and S\&T for SHS. In 2012 the Ministerial Review, which reflected on the performance of the NSI in relation to the 1996 White Paper, indicated poor responses to market and social demand and an under-conceptualised and under-developed role of social innovation in the NSI. The 2019 White Paperfocussed on ST with the intentional focus on impact and attaining development objectives.

The DSI's understanding of the notion of inclusive development is development focussed on promoting access, participation and benefitting from the STl system in a way that buildscapabilities, unlocks opportunities and includes the living conditions of all. The STl system needs to contribute to the alleviation of poverty and the reduction of inequality, ensuring that the system contributes to transforming So uth Africa.

The ma in pillars of the IID Strategy within the context of the White Paper are: 
- Innovation for basic service delivery: Although household access to basic services has improved substantially since 2002, there rema in under-served areas where accelerated access and improved capacity to deliver and infrastructure maintenance are needed. Work done in universities, science councils, the private sector and non-profit organisations (NPOs) should contribute in these areas. In instances where govemment has invested in the development of technology solutions, there are no clear policies relating to the adoption and acquisition of these technologies. Policy intents relate to public procurement as being key to further innovation, supporting commercialisation of publicly funded IP, exploiting new sources of growth, focussing on ICT and the 4IR and strengthening govemment's role as an enabler of innovation.

- Innovation for local economic development (ILED): One of the key priorities in this area is ensuring that everyone is able to benefit from investments in STl and have access to and partic ipate in STl activities and opportunities. Policy intents relate to increasing the spatial footprint of innovation in South Africa, innovation to revitalise existing sectors as well as strengthening govemment's role as an enabler for innovation. ILED is premised on the following priorities: strengthening local systems of innovation through enhancement of local ST\&l capabilities, capacities and networks, catalysing local industries/ clusters through innovation-centred systemic interventions and enabling local govemment and local economic development actors to foster innovation-driven LED. In supporting social and grassroots innovation and increasing the social footprint, it is best to align with provincial strategies. Acknowledging that there are many actors supporting grassroots innovators, it is important to work together in a way that maximises output, effic iency, and eliminates duplic ation.

- Youth ST: Priorities in this area concem the creation of economic opportunities for youth through ST, ensuring that the STl system responds to the needs of young people and contributes to reducing unemployment of youth, and interventions that respond to young people who are not employed or in education and training.

- Enabling policy environment: In the commitment to invest in certa in technologies, the acquisition of the technologies has to be enabled through responsive and supportive policies. As a United Nation member state, South Africa has committed to hamessing ST for the developmentagenda by responding to the Susta inable Development Goals (SDGs). 
- Upgrading the $M \& E$ capacity and policy capacity of the NSI: M\&E is essential in order to be able to measure the impact of investment in STl and the capacity of the state to be able to deliver on its mandate.

\section{DISCUSSION: QUESTIONS/ COMMENTS}

\section{(Question) Gauteng Department of Ec onomic Development (GDED):}

- How doesDSI see the role played by provinces in terms of contributing to the White Paper?

- In terms of opportunities for collaboration, the Gauteng Provincial Govemment is in a process of revising the Gauteng Innovation Strategy and has partnered with several entities to jointly ensure that the revised provincial innovation system applies to current requirements both domestic ally and globally. The presentations provide a sense of how we can adopt the DSI White paper in our provincial dynamics and together with the Gauteng Provincial Forum (to be launched soon) find opportunities for collaboration. I will communic ate with colleagues from the DSI a fter this workshop.

(Response), Mr Imraan Patel, DS: The comments a re welc omed. The DSI is already working with the Gauteng Province with the idea of having a joint consulta tion to ensure a lignment in a rea s of foc us and responsibility.

(Question): Is there a system in place that allows monitoring of lessons leamt from a project management point of view? This is important because good ideas need to be implemented. Is there a scientific view of the country's political system? This is crucial. Do we understand the tools and the powers of the persons that are approached and are we packaging them the right way?

(Response) Ms Nonhlanhla Mkhize, DS: We a re inc reasingly being asked about the contribution, value and impact of our investment in tems of improving the quality of life of ordinary South Africans. At the political level, we are seeing a greater appetite for innovation. The question is, if we have so many solutions that respond to inclusive development, why are we not seeing them? We are responsible to ensure policy coherence and alignment so that a sector that potentially absorbs the technologies developed by other sectors is not hindered by procurement legislation. In terms of project management, a range of projects have been implemented by other departments and partners beyond the DSI 
and key lessons have been leamt. One such lesson is that working in a complex space requires project management skills. It is nec essary for us to improve these skills.

(Response) Mr Imraan Patel, DS: There is a lot of science behind the politicalsystem. There isa difference between the existence of information and knowledge and its use. Nowadays there is a much greater focus on evidence-based policymaking. Govemment now has a well-developed $M \& E s y s t e m$ and there isa seriesofeva lua tionsof the DSI'sbig programmes. Much of this concems the policy-making process and how politic seither hampers or enhances this process. Even though the science is available, the problem is not easy to solve because the country's political set-up is complexand dynamic.

\section{BREAR-AWAYSSSSIONS}

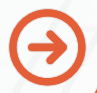

Partic ipants were asked to discuss and respond to the following points in the break-away groups:

- What are the ongoing initiatives happening in your sector (beyond govemment)?

- How should information about the initiatives be made available?

- What opportunities a re there for collaboration?

- What suggestions do you have in tems of policy intent interventions?

\section{SESSION ONE: SQTFOR SUSTAINABIE HUMAN SETIEMENIS}

\section{Chair: Mr Ephraim Phalafala, Deputy Director: S\&T for Sustainable Human Settlements, Department of Science and Innovation, DS Presenter: Ms Nonhlanhla Mkhize, Chief Director: Innovation for Inclusive Development, Department of Science and Innovation, DSI}

SHS supports the experimentation of S\&T-based innovations for tackling poverty including the c rea tion of susta ina ble jo b a nd wea lth opportunities, building SHS, and enhancing the delivery of basic services, and focusses on innovative and mature tec hnologies that do not yet have widespread 
application, but have the potential to achieve govemment's broad development objectives.

Current programmes and SHS projects are:

- Innovative Partnership for Rural Development programme: Basic servic esusing technologiesare deployed in rural a reasthrough priority district munic ipa lities to demonstrate how innovation can improve the lives of people.

- Accelerating Susta inable Water Service Delivery project: The project is focused solely on altemative ways of delivering water senvices to rural communities using S\&Tand has been implemented in four district munic ipalities.

- Technology for Rural Education and Development programme: The programme addressesa whole range of innovationsusing technology to improve education and has been implemented in the Eastem Cape in partnership with the Department of Basic Education. Lessons leamt from the programme were used to inform Operation Phakisa.

- SHSRoadmap: The roadmap is currently being developed in partnership with the CSIR in order to enhance the uptake of innovations in the SHS space

- Development of knowledge products and decision support tools and hosting leaming interventions: These interventions provide assistance with implementing new technologies

- Sanitation Technologies Demonstration Programme: Testing a wide range of technologies in the sanitation sectorfor application in local munic ipalities

- Grassroots Innovation Programme: The programme has been implemented and would be up-scaled in acknowledgement of the fact that innovation can happen outside the $R \& D$ space.

Some of the relevant sector policies that are taken into account in charting the way forward in SHSare:

- NDP

- Back to Basics Programme

- National Sa nitation Policy

- The New Urban Agenda 
- SDGs

- White Paper on Human Settlements

- National e-Govemment Strategy.

Policy intents of the White Paper that have a direct link to SHS a re:

- Adopt a broader conceptualisation of innovation beyond R\&D

- Use public procurement as a vehicle to further innovation

- Support innovation for social and grassroots innovation to enable all the sectors of society to access the knowledge infrastructure

- Strengthen govemment's role as an enabler for innovation.

Proposed interventions to feed into the Decadal Plan include:

- Full implementation of the G rassroots Innovation Programme

- Technology Acquisition and Deployment Fund

- Smart Cities and Green Villages demonstration

- Innovation for Basic Servic es Delivery

- ICTfor Development (ICT4D).

\section{DISCUSSION: QUESTIONS/COMMENTS}

(Comment) Mr Ephraim Phalafala, DSI: The DSI is in discussions with the dti about their programme that addresses commercialisation of ideas. The plan is that the DSI will take ideas (proof of concept) until the commercialisation stage and then the dti will assist with the commercia lisation process. Currently, the details of the collaboration a re being outlined.

\section{COMMENT:}

Developing Sma rt cities will require broad stakeholder involvement and the concept needs to be clearly understood in the local context. 
(Response) Mr Ephraim Phalafala, DS: There will be broad involvement in the implementation of the Smart cities concept. The move towards Smart cities (and Big Data) presents many opportunities and cannot be avoided, particularly in the context of increasing populations and urba nisation.

(Response) Ms Nonhlanhla Mkhize, DSl: Govemment is but one of many stakeholders in the conversation about SHS, which is addressed through a framework that has to do with the deployment of innovative building technologies with Smart cities as one of the focus areas. The South Afric an Local Govemment Asso ciation (SALGA) is developing a concept doc ument on Smart cities. The DSI is party to that and its role is to bring as many people as possible into the conversation.

Question: How will the Technology Acquisition and Deployment Fund be funded?

(Response) MrEphraim Phalafala, DS: There will not be a d d itiona I fund ing . Existing resources will have to be reprionitised.

(Response) MsNonhlanhla Mkhize, DS: Inno va tive tec hno logy solutionsa re being developed by several institutions but are not necessa rily rea ching the deployment stage even when govemment is the target client. The DSI is committed to fund these up to the end of the experimentation phase, but an enabling policy is essential in order to hamess ST in tems of delivering basic services. The extent to which procurement policy enables deployment of innovative technology solutions has to be considered. A further challenge is that there are pockets of funding for STl distributed across govemment departments. The Fund will take care of the acquisition of the technology, but deployment of the technology requires many components to work together.

(Question) Mr Ephraim Phalafala, DS: What is your orga nisa tion's c urrent foc us and what a rea of ST is it involved in?

\section{RESPONSES RROM PARIICIPANTS:}

Response 1: Universities are producing high level skills that feed into whatever is necessary. Some universities function better than others. Universities undertake research so that their students can graduate with higher degrees. The research is foc used on whatever the professors can 
get money to do research on. Doing research is not possible without money.

Response 2: A comment was made that many lecturers are not doing research. It should be clear that they are not doing research because they are busy teaching very large classes of students. They are the users and implementers of research and need support in order to be able to inspire and inform students using the latest research. Their students become planners in munic ipalities and take on other important roles in society.

Response 3: We have a significant amount of competent and skilled people in high end technology. One thing that has alwaysbeen missing is coordination. The proposal is to have an innovation forum that is ongoing and allows the public and private sectors as well as students to engage to resolve real life problems on an ongoing basis. This structure could be headed by DSI but involve everyone, a cross sectors and at all levels. This way IP will not collect dust because there will be direct access to the market, and it will help munic ipa lities to unblock bottlenecks and resolve service delivery problems. A space needs to be created for energy and intelligence to come together to resolve problems. Let us create the conversation that will help move things forward.

Response 4: A vast source of innovation is available from universities in the form of Master's and PhD theses that a re gathering dust. They a re not taken to the next step. This is a waste. The data should be mined to see what ideas could be taken further.

Response 5: The CSIR is developing a 10-year roadmap and the Department of Human Settlements has a framework for innovation and transformative technologies. The roadmap is seen as a response to that and aims to instil a culture of innovation across a wide spectrum of stakeholders and contribute to developing an innovation pipeline. The principle idea is to look at how to foster innovation throughout the value chain and unlock the areas that do not flow. Numerous platforms already exist but a re not known to everyone. Participants a re invited to collaborate in the development of the roadmap.

Response 6: The CSIR has had thematic, cross-disc iplinary disc ussions on Smart cities for two or so years. A lot of considerable thinking has taken place around this already. Some work has also been done on 
neighbourhoods of the future and we are now looking at township economies and Smart technologies. We can also give input on green villages and Smart cities.

Response 7: Denel has substantial experience in technology solutions for va rious a spect s of SHS.

Response 8: We have recently been focussing on the management of drones in the context of a ir traffic control. There a re many opportunities in this a rea, especially in terms of delivering servic es to rural communities that a re diffic ult to access.

Response 9: We focus on ICT skills development and fund programme related to ICT. We are in a process of establishing a 4IR unit with funding from govemment. There will be a foc us on developing the new skills that will be required in preparation for the 4IR. Govemment institutionsopera te in silos and collaboration needs to be improved, partic ularly in terms of cross-funding. The infrastructure of some of the rural programmes does not allow for implementation of 4IR technologies.

(Comment) Ms Nonhlanhla Mkhize, DS: The private sector will fund ideas, but there isa need to ensure that the ideasa re ta ken forwa rd. There needs to be coordination between the creation of ideas and implementation of those ideas. With respect to an innovation forum, the White Paper suggests a high-level structure, but the forum is more about how to use existing mechanisms to ensure that the actions needed to move ahead are happening.

\section{COMMENT:}

Although much has been done to put in place policies, implementation of those policies have not been good. It would be very useful if we can understand what policies are getting in the way of implementing innovative technology solutions to help resolve social and economic challenges. This important aspect should be investigated.

(Response) MsNonhlanhla Mkhize, DS: We would a p precia te partic ipants' specific polic ' 'pain points' and suggestions. 


\section{COMMENTS:}

- The DPME is currently working on evidence mapping and synthesis. Through evidence maps we are able to package data and information from govemment organisations to ensure that evidence is a vailable when policy decisions are made. We also try to speed up the process by getting ITsolutions to help with the extractions.

- We should talk about the standards that need to be in place in orderforpeople to collaborate. There should be a non-negotiable framework that people need to meet in order to get the line of support. Other issues also need to be discussed, such as who makes the decisions in that line of collaboration. A template will help. Roles and responsibilities in tems of collaboration need to be clear. A lot of people start off engaging but never see the process through. At what point does who become liable for what resources in order to a chieve an end result. Collaboration will move ahead if such standards are in place.

- Since around 2010, reporting on national projects has slowed down. A number of projects have been established but there is a lack of reporting on these projects and they fade away over time. This is a reason for many good ideas becoming white elephants. Govemment departments that initiate projects in the provinces should considera more hands-on type of reporting on those projects. This problem also has to do with management.

(Comment) Ms Nonhlanhla Mkhize, DS: Partic ipants will be invited to a seminar with SALGA to discuss Smart Cities and concepts. There a re pockets of work across the country, each working on aspect of what this means. Work is being done by South African institutions, but there is work that is extema lly funded and influences how we should define Sma rt cities in the South African context. This is a complex space that needs clarific ation and definition, and we need to discuss what Smart concepts mean for South Africa. 


\section{SESSION TWO: INNOVATION FOR LOCAL ECONOMIC DEVELOPMENT(ILED)}

\section{Chair: MrEric Watkinson, Department of Science and Innovation, DS Presenter: Ms Busisiwe Ntuli, Director: Tec hnology for Sustainable Livelihoods, Department of Science and Innovation, DSI}

The 1996 White Paper was silent on the sub-national levels of the NSI and foc used on the formal institutions in the NSI. The DSl's ILED strategy seeks to realise some of the aspirations of the 2019 White Paper, particularly in relation to LED, building on the other levels of the NSI towa rdsa prosperous and inclusive society and economy.

Policy intents of the White Paper that link to LED and speak specific ally to ILED refer to increasing the spatial footprint of innovation in South Africa, supporting social and grassroots innovation and strengthening govemment's role as an enabler for innovation, ensuring that local municipalities play an active role in fostering innovation driven LED. The 2019 White Paper moves towards transforming the geography of innovation in South Africa, ensuring that the location of innovation activities expands beyond urban a reas to other peripheral spaces and attracts grassroots innovators in the loc al context. The DSI recognises that regional and local economies play a critical role in national inclusive growth and a knowledge economy.

There are a number of global examples that support the focus on regions and local economies, transforming the geography of innovation to avoid the perpetuation of uneven growth and encourage inclusion, while acknowledging the potential of the 4IR to further widen inequalities and hinder inclusive economic development.

A study on the state of innovation in local economic planning and execution in South Africa was conducted in 2015. The findings of the study became key to how ILED was conceptualised, partic ula rly in terms of effectively driving inclusive development, job creation and poverty elimination.

The three pillars of ILED contribute to reversing historical geographies of innovation and building local knowledge economies that contribute to inclusive development. These are:

- Strengthening local ST capabilities by ensuring that capacity exists 
(partic ularly in margina lised spaces) by way of infrastructure and human capability.

- Catalysing local industries, clusters and value-chains through exploitation of STI (systems of innovation and production)

- Enabling local govemment to foster innovation driven LED.

The DSI has introduced instruments and programmes in order to realise the ILED objectives, summarised as follows:

\begin{tabular}{|c|c|}
\hline Objective & Programmes and Instruments \\
\hline $\begin{array}{l}\text { Strengthening local innovation } \\
\text { systems }\end{array}$ & $\begin{array}{l}\text { - Living Labs Fund (to support } \\
\text { grassroots innova tors) } \\
\text { - Tools for Local Innovation } \\
\text { Adva ncement (T4LA) }\end{array}$ \\
\hline $\begin{array}{l}\text { Catalysing loc al ind ustries and } \\
\text { value-chains through STा }\end{array}$ & $\begin{array}{l}\text { Systems of innovation and } \\
\text { production - sector development }\end{array}$ \\
\hline $\begin{array}{l}\text { Enabling local govemment to } \\
\text { foster innovation-driven LED }\end{array}$ & $\begin{array}{l}\text { - Innovation champions for LED } \\
\text { - Decision support to ols: In-Touch } \\
\text { Africa, Aqua culture app, T4பA } \\
\text { - Capacity }\end{array}$ \\
\hline
\end{tabular}

The DSl isworking c losely with the Depa rtment of Coopera tive Govema nce (DCOG) to incorporate ST in the new National Framework on LED. This enables the different spheres of govemment to speak collec tively about innovation and to have an LED strategy that informs the innovation agenda, seeking to improve how LED is conceptualised and ma na ged in So uth Afric a to effectively a dd ress unemployment, poverty a nd inequa lity (interpersonal and spatial).

The DSI will soon begin drafting the STI Decadal Plan, with a $n$ a rea of foc us on ILED. The DSI together with the DCoG was engaging municipalities to collect case studies in order to pilot some aspects of the revised National Framework on LED, while also creating awareness of and getting buyin for the framework as well as assisting municipalities to incorporate the innovation agenda in crafting their LED strategies and Integrated Development Plans (IDPs). 
Partic ipants were asked to point out the gaps in the ILED Strategy and the big initiatives that should be part of the Decadal Plan and consider partnering with the DSI in drafting the Plan.

\section{DISCUSSION: QUESTIONS/COMMENTS}

(Question) Prof. Kobus Elof, UP: I c a nnot understa nd exa c tly how innovation can be taken to the rural areas and am concemed that money going to rural areas will provide very little retum on investment. Are you ta lking about the application of innovation in rural a reas? This would help tremendously. The main advantage of people in rural areas is the plant diversity a vailable to them. This is extremely valuable. I cannot think of innovations in rural areas that can lead to job creation. UNP has done substantial research on valuable medic inal plants for human and a nimal consumption. Despite South Africa's rural plant diversity, there is often little inc ome eaming prospect from these species. What could innovation in other sectors of the rural ec onomy offere.g. services (water, elec tric ity, refuse)?

(Response) Ms Busisiwe Ntuli, DS: The question is a hot one, perhaps the Green Economy offers altemative rural income options. The points raised touch on a number of themes around application of knowledge or technology transfer versus inclusion in the innovation enterprise. There is a school of thought that subscribes to transfeming technology that is developed elsewhere to rural areas and hope that it works. This is not necessarily wrong, but from the innovation for inclusive development perspective, open innovation needs to be promoted and knowledge generation should be owned by more than a select few within the system. People within rural areascan innovate. There a re many examples of such innovations. Spacesare being created where people can test theirideas and advance the ideas into innovations.

\section{COMMENTS:}

- The concept of innovation as it is used in the presentations is confusing. Innovation is a process. Innovation for LED is different from innovation in LED. Concepts need to be clarified and used consistently or the discussion will remain at the level of policy intents and not move to specific policy actions. The White Paper does not offer conceptual clanity about the terms 
- "Innovation", "Science" and "Technology" and it is not clear whether it is Innovation in Local Economic Development or Innovation for Local Economic Development. In ILED where is the driver, the locus and how shall the benefits and costs of research and development be distributed? How can new practices and services / products reduce social exclusion and environmental costs and build human capacity. Do we always need to do "research" in order to innovate?

- Issuesto do with STI for inc lusive development a re not a dequa tely covered in the discussions and in White Paper. Questions about how to deal with the distribution of benefits and costs of $R \& D$ and existing technologies, how to ensure that $R \& D$ and new technologies do not widen exclusion and how to reduce the social and environmental costs of new technologies need to be addressed.

(Response) Ms Busisiwe Ntuli, DSI: ILED empha sizeso wnership of innovation by rural people- open innovation. It also foc uses on resource-poverty and the means to advance economic development, through participation. For example, ILED could focus on water scarcity and participation in the design and management of imigation systems. The importance of clarifying concepts is recognised and will receive the DSI's attention. ILED is based on the premise of local innovation and not just drawing from existing technologiesand transfering to different spa cesbut encouraging knowledge generation in the local context with an appreciation forlocal problems and creating partnerships to collaboratively find solutions to local problems.

\section{(Comment) Prof. Norman Marwashe, Agric ultural Research Counc il (ARC):}

Indigenous Knowledge Systems (IKS) should feature more prominently. There must be clarity about what is meant by 'innovation'. It is often associated with universities, but it is much broader than that. There are many prototypesand new products that do not reach commercialisation beca use of the fund ing required to sca le-up. If ILED isto be well understood by everybody, it will be important to engage beyond the formal research institutions to people on the ground. The tribal authorities need to be brought in the discussions on ILED. How should one tap into indigenous knowledge about locally a vailable resources in rural areas? Who a re the practical people who may develop and scale village "prototypes", so that they see the day of light? 
(Response) Ms Busisiwe Ntuli, DSl: Perhaps tra ditional a uthorities a re best able to advise. Spaces and the footprint of innovation relate to how to include in terms of infrastruc ture and human ca pability. Thisa rea of work is expressed in the White Paper, which talks about the need to decentralise innovation and $R \& D$ activities and have areas where there is focus on specific local problems. This is one way of extending the benefits of innovation. Some of the instruments being introduced (funding as a key instrument) ensure that otherplacesand groupsa re reached and able to partic ipate in the innovation enterprise. This also extends the benefits of innovation and ensures that inclusion does not rema in an aspiration. The $M \& E$ component would look at these aspects. Indicators in the Decadal Plan will be very specific to how the benefits on the ground are realised.

\section{(Comment) Prof. Refiwe Phaswana-Mafuya, North-West University (NWU):} NWU's Mafikeng campus is located in in a rural area. We have had successful engagements with local communities about incorporating research not the work being done locally in order to maximise production and enhance LED. Innovation is not mutually exclusive. The more universities work with communities, municipalities and people at the grassroots level, the more can be achieved. Universities continue to try to not be ivory towers but to work with communities on issues that impact the daily lives of ordinary people.

(Response) Ms Busisiwe Ntuli, DS: There certainly a re examples of collaboration between universities and rural communities. Nevertheless, there are spaces where this is a serious disconnect between universities and communities, and where communities are simply used as research subjects and do not participate in the knowledge generation process. The concept of open science is not always embraced equally across the board. A lot can still be done in terms of strengthening the linkages. Any local institution ought to support LED and archaic research practices need to be done away with. As Universities with an interest in rural development, how do we foster real collaboration- during MSc / PhD research? For example, at North-West University there has been work with farmers on the importance of kraal manure. North-West University also has a focus on living labs.

(Response) Ms Busisiwe Ntuli, DSI: There is a specific focus on IKS within the DSI and all forms of knowledge are embraced and open science is encouraged. The new White Paper is very deliberate about embracing all sorts of innovation and ensuring that innovation serves all spaces. 
Universities can adopt T4LIA's Open Science approach, although it is currently rare to do so. University of Venda is working in a similar way to North-West University

(Comment) Dr Nthabiseng Motete, ARC: Valuable lessons have been lea $\mathrm{mt}$ from the accessand benefit sha ring programmes, but these appear to be exclusive to the environment and biodiversity sector and should be brought into the discussion on ILED. The dichotomy in all aspects of development influences the way we think about innovation in the local economy. There needs to be a merge between universities and places where technology is developed and applied. What are the prospects for opening new universities in more rural localities, as was the case with Sol Plaatjie University? With the passage of time we expect a number of rural areas to densify and what looks "rural" today may be dramatic ally different in 10 years time. How shall DEA's access and benefit sharing legislation be applied in rural areas?

(Response) Ms Busisiwe Ntuli, DS: Agricultural colleges may bridge the gap in certa in a reas.

(Comment) Ms Nomfundo Mkhaba, Durban South Community Peace Builders: My greatest concem is how to get plans into one coherent place, where the warm bodies to do the work are too few, where ward councillors are an entry point to planning in a community. Indigenous languages cannot be in isolation and language development needs to be promoted. We are looking at the prospects of leaming in language, leaming with language, leaming and language and leaming through language so we can shift community discourse and the reaction to change. When talking about application of innovation in rural areas, you need to talk about my development and my self-actualisation in my thoughts which are in my language. Indigenous language development is a crucial a spect in understanding polic iesand being able to participate in the implementation of plans.

\section{(Response) Ms Busisiwe Ntuli, DS:}

I agree that language has been a bamier to accessing the economy, education, govemance and so on. There needs to be a focus on language when talking about inclusion and participation a local level.

Comment, The Innovation Hub: Based on our experience, grassroots innovation is a very difficult area to go into. From the presentations, 
very little resources and attention have been given to the need for collaboration, particularly in terms of planning between different govemment departments. One of the Key Performance Indicators (KPIs) of ILED should be collaborative funding allocation that encourages players in the innovation space to work together. Baseline studies are needed to identify and map who is doing what is the various provinces and local munic ipa lities. Coord ination is key.

(Response) Ms Busisiwe Ntuli, DS: Reso urc e a lloc a tion for Loc a I Ec onomic Development is not great, although it is getting better. The LED fra mework offers the prospect that there shall be improved coordination/funding of LED a mongst the National, Provincial and Local spheres of govemment.

(Comment) Mr Ellis Levember, SA Essential Oils: SA Essential O ils Business Incubator (SEOBI) has leamt that there needs to be breathing space for innovation to take place, forlocal value-chain innovation to take place. This is especially the case when young people are involved. It is good to see that business has been invited to discuss these matters. We often see good innovation, but it does not get commercialised. I want to see systems with inputs and outputs through processes. LED cannot exclude the rural areas, particularly as we look to the future. People must be helped to develop their solutions to their problems. Future scientists will have to come from the rural areas.

(Response) Ms Busisiwe Ntuli, DS: Co-aged-innovation seems to be workable.

(Comment) Ms Huni Phala, South Afican Local Govemment Association (SALGA): SALGA is working with the CSIR towards regenerating small towns. Human capacity is a challenge in local municipalities in rural areas. They struggle to drive provincial and national strategies at local level and require assistance, particular if they a re to implement ILED. The forum needs to agree on how best to coordinate the planning for ILED. My greatest concem is how to get plans into one coherent place, where the warm bodies to do the work are too few, where ward councillors are an entry point to planning in a community.

(Response) Ms Busisiwe Ntuli, DS: The coordination issue has been problematic for a long time but there have been improvements. The starting point in putting together the Decadal Plan will be to map what initiatives are happening across the country and who is doing what. 
Proposed structures of the National Fra mework on LED will ensure that LED is a priority and that there is coordination a cross departments a nd all tiers of govemment. We will take stock of the progress in this a rea in five years' time. We encourage collaboration at all levels. SALGA and DCoG are best placed to lead the conversation about how to ensure that planning is coord inated and that there is participation from all sta keholders.

\section{REPORT BACKFROMTHE BREAK- AWAYSSSSIONS}

\section{SESSION 1: MrEphraim Phalafala, DS}

- The universities produce knowledgeable and skilled graduates that are helpful to the Human Settlements sector and are willing to cooperate.

- University lecturers should be supported in their important task of tea ching large groups of students to become skilled and capable public servants.

- Although high end technologies are available, there is a lack of coordination to bring these to implementation. Innovation forums are needed where innovators can meet with stakeholders on an ongoing basis to facilitate collaboration.

- Data produced in Master'sand PhD theses should be mined in order to take the innovations forward (particularly relevant in Engineering and Built Environment).

- The CSIR is developing a roadmap of all the pipeline technologies in the human settlements sector. A framework is being developed by the Department of Human Settlements to complement the roadmap.

- The CSIR is working in the a rea s of smart cities, sma rt infrastructure and neighbourhoods of the future, and the revitalisation of township economies. There should be a focus on knowledge sharing and best practices. 
- Drones are being used increa singly for service delivery purposes, but drone traffic needs to be managed in line with a ir traffic control regulation.

- Input was given on skills development in preparation for the 4IR undertaken by the Media, Information and Communic ation Technologies Sector Education and Training Authority (MICTSETA). Funding is available for the development of ICTskills and new skills needed for the 4IR.

- There is an evidence mapping and synthesis hub in the DPME that ensures that evidence (including evidence in relation to human settlements) is made available when policy decisions are made.

- It is necessary to put standards in place for collaboration.

- Projects initiated by national govemment for implementation at provincial level should be well and consistently monitored. Reporting is crucial in this respect.

\section{SESSION 2: MrEric Watkinson, DS}

- Several participants sha red existing initiatives in LED. Others widened the scope to foc us on baselines acknowledging what people alrea dy do and working with that as the basis for va rious govemment departments to effectively plan and work together.

- In general, the idea of decentra lising innovation to local economics is accepted but people mostly raised concemsabout the entry point.

- Organisations nationally (such asSALGA) could provide a way for planning to be coordinated.

- One of the most pressing matters is how to represent the problems people are experiencing and what the priorities a re in the short-, medium and long-term, and how to allocate budget and evaluate the use of limited resources.

- Partic ipants spoke of the cost and benefits of investment.

- The language ba mier does not encourage inclusion and hampers buy-in to LED plans, mapsand polic ies. If IDPs represent a conceptual, language and access problem, it could be true that rural Spa tial Development Fra meworks are much worse. Perhaps spatial planning at a smaller-sc ale than 1:50 000, say 1:10 000 
represents an opportunity. The development of community-based spatial plans has proven to have worked in a number of urban informal settlement upgrades and there is no reason why similar partic ipa tory approaches (to layout for instance) would not work in rural a reas.

\section{WAYFORWARD}

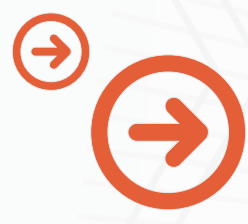

Ms Mkhize thanked participants for having availed themselves for the seminar. She ind ic ated that the presentations and report from this semina $r$ would be shared with participants and they would be invited to give inputs on the report as well as additional suggestions in response to the questions posed to the breakaway groups. Participants were also invited to engage directly with the DSI offic ials responsible for the White Paper. The following email addresses should be used: busisiwe.ntuli@dst.gov.za or Tshepang.mosiea @dst.gov.za

Partic ipants would be invited to a number of further engagements that have been planned in preparation for drafting the Decadal Plan. Some of the issues to be addressed as part of better hamessing STl for South Afric a development priorities include the responsiveness of leg islation, the role of Higher Education Institutions in developing the relevant skills and the need for funded research projects to make tangible inputs towards the realisation of national development priorities. 


\section{AMNEXUREA: \\ USTOF \\ PARIICIPANTS}

\begin{tabular}{|c|c|c|c|}
\hline Thie & Name & Sumame & Organisation \\
\hline $\mathrm{Dr}$ & Stuart & Ali & Precision Medic ine for Africa \\
\hline $\mathrm{Mr}$ & Lucas & Baker & Fofa ka Nong NPO \\
\hline $\mathrm{Mr}$ & Jay & Bhagwan & $\begin{array}{l}\text { Water Research Commission } \\
\text { (WRC) }\end{array}$ \\
\hline Ms & Portia & Bhila & University of Venda \\
\hline $\mathrm{Dr}$ & Gerda & Botha & $\begin{array}{l}\text { So uth Afric an Counc il for } \\
\text { Natural Sc ientific Professions } \\
\text { (SACNAP) }\end{array}$ \\
\hline Dr & Siya vuya & Bulani & $\begin{array}{l}\text { Academy of Science of South } \\
\text { Africa (ASSAf) }\end{array}$ \\
\hline Ms & Rebecca & Campbell & Engineering News \\
\hline Ms & La etitia & Cook & University of Pretoria (UP) \\
\hline Prof & Robin & Crewe & UP \\
\hline Prof & Duncan & Cromarty & UP \\
\hline Ms & Peta & de Jager & CSIR \\
\hline $\mathrm{Mr}$ & Brandon & Dickens & HBS Technologies \\
\hline Ms & Joy & Dickens & HBS Technologies \\
\hline $\mathrm{Mr}$ & Klaas & Dikobo & Rootstock Systems \\
\hline $\mathrm{Mr}$ & Msimelelo & Dingiswayo & ASSAf \\
\hline Prof & Chrisna & Du Plessis & UP \\
\hline Prof & Kobus & Eloff & UP \\
\hline Prof & Joseph & Francis & University of Venda \\
\hline $\mathrm{Mr}$ & John & Fraser & ZA Confidential \\
\hline $\mathrm{Mr}$ & Mthunzi & Gasa & Afric a Unite \\
\hline Ms & Sue & George & $\begin{array}{l}\text { Intemational Association for } \\
\text { Impact Assessment South } \\
\text { Afric a (IAIAsa) }\end{array}$ \\
\hline
\end{tabular}




\section{Thie Name}

Dr Richard
Glover

\section{Organisation}

Intemational Science Council Regional Office for Africa (ISC ROA)

$\mathrm{Mr} \quad$ Uvesh

Gopichund

Air Traffic and Navigation

Services (ATNS)

\begin{tabular}{|c|c|c|c|}
\hline $\mathrm{Mr}$ & Grant & Greyling & The Innovation Hub \\
\hline Ms & Nadia & Grobler & ASSAf \\
\hline $\mathrm{Mr}$ & Khonzi & Hlophe & ATNS \\
\hline $\mathrm{Dr}$ & Trudi & Joubert & UP \\
\hline Ms & Phyllis & Kalele & ASSAf \\
\hline $\mathrm{Mr}$ & Dominic & Kgaabi & $\begin{array}{l}\text { National Research Foundation } \\
\text { (NRF) }\end{array}$ \\
\hline Prof & Nnenesi & Kgabi & North-West University (NWU) \\
\hline $\mathrm{Dr}$ & Leti & Kleyn & ASSAf \\
\hline $\mathrm{Mr}$ & Theuns & Knoetze & CSIR \\
\hline $\mathrm{Dr}$ & Mpho & Lekgoathi & $\begin{array}{l}\text { South African Nuclear Energy } \\
\text { Corporation (NEC SA) }\end{array}$ \\
\hline $\mathrm{Mr}$ & Tshepiso & Lekoma & $\begin{array}{l}\text { Department of Tra de and } \\
\text { Industry (the dti) }\end{array}$ \\
\hline $\mathrm{Mr}$ & Phatu & Letsoalo & $\begin{array}{l}\text { Office of the Premier: } \\
\text { Limpopo Province }\end{array}$ \\
\hline $\mathrm{Mr}$ & Ellis & Levember & SA Essential Oils \\
\hline Ms & Precious & Lukhele & $\begin{array}{l}\text { Department of Science and } \\
\text { Innovation (DSI) }\end{array}$ \\
\hline $\mathrm{Dr}$ & Peace & Mabeta & UP \\
\hline $\mathrm{Dr}$ & Tebogo & Mabotha & ASSAf \\
\hline Ms & Pheladi & Mabotha & Moloko Kwizeen \\
\hline Ms & Paris & Mabotha & Spark Schools \\
\hline Ms & Mandisa & Magwaza & $\begin{array}{l}\text { Department of Planning, } \\
\text { Monitoring and Evaluation } \\
\text { (DPME) }\end{array}$ \\
\hline $\mathrm{Mr}$ & Mmakgabo & Maheya & SABS \\
\hline Ms & Nompumelelo & Mahlangu & ASSAf \\
\hline
\end{tabular}




\begin{tabular}{llll} 
Tite & Name & Sumame & Organisation \\
\hline $\mathrm{Mr}$ & Tsepo & Majake & ASSAf \\
\hline $\mathrm{Dr}$ & Clifford & Malaka & MICTSETA \\
\hline $\mathrm{Mr}$ & Bongani & Maluleka & ATNS \\
\hline $\mathrm{Ms}$ & Nkhensani & Maluleke & $\begin{array}{l}\text { South African Local } \\
\text { Govemment Asso cia tion } \\
\text { (SALGA) }\end{array}$ \\
\hline $\mathrm{Dr}$ & Misheck & Mulumba & $\begin{array}{l}\text { Agricultural Research Council } \\
\text { (ARC) }\end{array}$ \\
\hline $\mathrm{Ms}$ & Vuyisile & Mangena & Sol Pla atje University \\
\hline $\mathrm{Mr}$ & Maokane & Manala & ATNS \\
\hline $\mathrm{Ms}$ & Marvin & Mandiwana & ASSAf \\
\hline $\mathrm{Mr}$ & Stanley & Maphosa & ASSAf \\
\hline $\mathrm{Prof}$ & Noman & Marwashe & ARC \\
\hline $\mathrm{Ms}$ & Nthabiseng & Maseko & NWU \\
\hline $\mathrm{Mr}$ & Floyd & Masemola & ASSAf \\
\hline $\mathrm{Ms}$ & Neo & Mashilo & ASSAf \\
\hline $\mathrm{Mr}$ & Sobuza & Mathebula & Sol Pla atje Munic ipa lity \\
\hline $\mathrm{Ms}$ & Sibusisiwe & Matiya & ISC ROA \\
\hline $\mathrm{Dr}$ & Jennifer & Mirembe & $\begin{array}{l}\text { National Department of } \\
\text { Human Settlements (DHS) }\end{array}$ \\
\hline $\mathrm{MS}$ & Nomfundo & Mkhaba & $\begin{array}{l}\text { Durban South Community } \\
\text { Peace Builders }\end{array}$ \\
\hline $\mathrm{Dr}$ & Ntabiseng & Motete & ARC \\
\hline $\mathrm{Dr}$ & Alina & Mofokeng & ARC \\
\hline $\mathrm{Mr}$ & Mosibudi & Mokoele & the dti \\
\hline $\mathrm{Mr}$ & Mathala & Mokwele & $\begin{array}{l}\text { Department of Agric ulture, } \\
\text { Forestry and Fisheries (DAFF) }\end{array}$ \\
\hline $\mathrm{Mr}$ & Mmakwena & Molala & $\begin{array}{l}\text { National School of } \\
\text { Govemment }\end{array}$ \\
\hline $\mathrm{Mr}$ & Thabiso & Molemohi & $\begin{array}{l}\text { South Africa Bureau of } \\
\text { Standards (SABS) }\end{array}$ \\
\hline $\mathrm{Dr}$ & Ghaneshree & Moonsamy & CSIR \\
\hline
\end{tabular}




\begin{tabular}{|c|c|c|c|}
\hline Thite & Name & Sumame & Organisation \\
\hline Ms & Thato & Morokong & ASSAf \\
\hline $\mathrm{Dr}$ & Salerwe & Mosebi & $\begin{array}{l}\text { University of So uth Africa } \\
\text { (UNISA) }\end{array}$ \\
\hline Ms & Makgomo & Mosoma & DAFF \\
\hline Ms & Nomsa & Motsoene & the $d t i$ \\
\hline Ms & Mahali & Motsoeneng & ATNS \\
\hline Ms & Thembani & Mtang wanika & ATNS \\
\hline $\mathrm{Mr}$ & Tha biso & Mudau & ARC \\
\hline Prof & John & Mugabe & UP \\
\hline $\mathrm{Dr}$ & Paul & Mungai & University of Cape Town (UCT) \\
\hline Ms & Lule & Mutafya & UP \\
\hline Dr & Mark & Napier & CSIR \\
\hline $\mathrm{Mr}$ & Chris & Ndala & NRG Media and Advertising \\
\hline Prof & Khathutshelo & Nephawe & SACNASP \\
\hline $\mathrm{Mr}$ & Tiyani & Ngoveni & DSI \\
\hline $\mathrm{Dr}$ & Luxon & Nhamo & $\begin{array}{l}\text { Intemational Water } \\
\text { Management Institute (IWMI) }\end{array}$ \\
\hline Ms & Shanna & Nienaber & WRC \\
\hline Ms & J acqueline & Nkate & $\begin{array}{l}\text { National School of } \\
\text { Govemment }\end{array}$ \\
\hline $\mathrm{Mr}$ & Bamy & Nkomo & $\begin{array}{l}\text { Motor Industry Bargaining } \\
\text { Council (MIBCO) }\end{array}$ \\
\hline $\mathrm{Mr}$ & Leonard & Nkuna & DPME \\
\hline Ms & Busisiwe & Ntuli & DSI \\
\hline Ms & Pfungwa & Nya muka chi & The Conversation \\
\hline $\mathrm{Dr}$ & Pertina & Nya mukondiwa & University of Venda \\
\hline $\mathrm{Mr}$ & Willie & Nyoffu & $\begin{array}{l}\text { Cooporative Govemance } \\
\text { and Traditional Affa irs } \\
\text { (CoGTA) }\end{array}$ \\
\hline $\mathrm{Mr}$ & Lamy & Obi & $\begin{array}{l}\text { Sefako Makgatho Health } \\
\text { Sc iences University }\end{array}$ \\
\hline Ms & Meshendri & Padayachy & the $d t i$ \\
\hline
\end{tabular}




\begin{tabular}{|c|c|c|c|}
\hline The & Name & Sumame & Organisation \\
\hline $\mathrm{Mr}$ & Imraan & Patel & DSI \\
\hline Ms & Huni & Phala & SALGA \\
\hline $\mathrm{Mr}$ & Ephraim & Phalafala & DSI \\
\hline $\mathrm{Dr}$ & Khutso & $\begin{array}{l}\text { Phalane- } \\
\text { Legoale }\end{array}$ & ASSAf \\
\hline Prof & Refilwe & $\begin{array}{l}\text { Phaswana- } \\
\text { Mafuya }\end{array}$ & NWU \\
\hline $\mathrm{Mr}$ & Boyse & Pillay & CSIR \\
\hline Ms & Mariana & Pumell & Agbiz Grain \\
\hline Ms & Sibongile & Radebe & $\begin{array}{l}\text { Technology Innovation } \\
\text { Agency (TA) }\end{array}$ \\
\hline Ms & Takalani & Ramutaga & the $d t i$ \\
\hline $\mathrm{Mr}$ & Ashaal & Roopchan & $\mathrm{TIA}$ \\
\hline Ms & Urszula & Rust & DSI \\
\hline Ms & Chanel & Schoeman & CSIR \\
\hline Ms & Ithuteng & Sekaledi & $\begin{array}{l}\text { Human Sciences Research } \\
\text { Council (HSRC) }\end{array}$ \\
\hline Ms & Gugu & Sema & MICTSETA \\
\hline $\mathrm{Dr}$ & Genevieve & Simpson & NRF \\
\hline $\mathrm{Mr}$ & Ameeth & Singh & Land Bank \\
\hline $\mathrm{Mr}$ & Rendani & Sitari & Private \\
\hline $\mathrm{Mr}$ & Phetole & Sithole & Sol Pla atje Municipality \\
\hline $\mathrm{Dr}$ & Amanda & Skepu & Mintek \\
\hline Prof & Vanessa & Steenkamp & UP \\
\hline Ms & Nicolene & Steyn & $\begin{array}{l}\text { SARChI Cha ir in Cities, } \\
\text { Law and Environmental } \\
\text { Sustainability }\end{array}$ \\
\hline Prof & Chris & Theron & UP \\
\hline $\mathrm{Dr}$ & Abraham & Thomas & Council for Geoscience \\
\hline $\mathrm{Mr}$ & Takalani & Tshika la ha & ATNS \\
\hline Ms & Nontando & Tusi & Recreate \\
\hline $\mathrm{Mr}$ & Sarel & Van derWalt & $\mathrm{TA}$ \\
\hline
\end{tabular}




\begin{tabular}{|c|c|c|c|}
\hline Tite & Name & sumame & Organisation \\
\hline Ms & Louise & Van Heerden & ASSAf \\
\hline Prof & Dawie & Van Vuuren & UP \\
\hline Ms & Carin & Van Zyl & DPME \\
\hline $\mathrm{Dr}$ & Christa & van Zyl & HSRC \\
\hline $\mathrm{Dr}$ & Gusti & van Zyl & UP \\
\hline Ms & Renate & Venier & ASSAf \\
\hline $\mathrm{Dr}$ & Hilton & Vergotine & ARC \\
\hline $\mathrm{Dr}$ & Janine & Victor & $\begin{array}{l}\text { South Afric an National } \\
\text { Bio diversity Institute (SANBI) }\end{array}$ \\
\hline $\mathrm{Dr}$ & Nokuthula & Vilakazi & UP \\
\hline $\mathrm{Dr}$ & Njeri & Wabin & HSRC \\
\hline $\mathrm{Mr}$ & Eric & Watkinson & DSI \\
\hline Prof & Brenda & Wing field & UP \\
\hline $\mathrm{Mr}$ & J ustin & Witten & $\begin{array}{l}\text { So uth African National Spa ce } \\
\text { Agency (SANSA) }\end{array}$ \\
\hline Ms & Diana & Zhou & DPME \\
\hline Ms & Barbara & Zyane & $\begin{array}{l}\text { Gauteng Department of } \\
\text { Economic Development } \\
\text { (GDED) }\end{array}$ \\
\hline $\mathrm{Mr}$ & Bheki & Zulu & $\begin{array}{l}\text { Companies and Intellectual } \\
\text { Property Commission (CIPC) }\end{array}$ \\
\hline Ms & Bongiwe & Zwane & ASSAf \\
\hline
\end{tabular}




\section{ANMEXURE B: LSTOF}

4IR 4th Industrial Revolution

ARC Agricultural Research Council

ASSAf Academy of Science of South Afric a

ATNS Air Traffic and Navigation Services

CIPC Companiesand Intellectual Property Commission

CoGTA Cooperative Govemance and Tra ditional Affairs

CSIR Council for Sc ientific and Industrial Research

DAFF Department of Agriculture, Forestry and Fisheries

DCoG Department of Cooperative Govemance

DHS National Department of Human Settlements

DPME Department of Planning, Monitoring and Evaluation

DSI Department of Sc ience and Innovation

GDED Gauteng Department of Economic Development

HSRC Human Sciences Research Council

ICT

IID

IKS

ILED Innovation for Local Economic Development

IP Intellectual Property

ISC ROA Intemational Science Counc il Regional Office for Africa

IT

IWMI

LED

$M \& E$ Information Technology

Intemational Water Management Institute Local economic development

MIBCO Motor Industry Bargaining Council

MICTSETA Media, Information and Communication Tec hnologies Sec-

tor Education and Tra ining Authority

$\mathrm{NACl} \quad$ National Advisory Counc il on Innovation

NDP National Development Plan

NECSA South African Nuclear Energy Corporation

NPO Non-profit organization

NRF

National Research Foundation

$\mathrm{NSI}$

National System of Innovation

NWU

North-West University

R\&D

Research and development 
S\&T

SABS

SACNASP

SALGA

SANBI

SANSA

SHS

SONA

ST

T4LA

TIA

the $d t i$

UCT

UNISA

UP

WRC
Science and Technology

South African Bureau of Standards

South Afric an Counc il for Natura I Sc ientific Professions

South Afric a Local Govemment Association

South Afric an National Biodiversity Institute

South Afric an National Space Agency

Susta inable Human Settlements

State of the Nation Address

Science, Technology and Innovation

Tools for Local Innovation Advancement

Technology Innovation Agency

Department of Trade and Industry

University of Cape Town

University of South Africa

University of Pretoria

Water Research Commission 



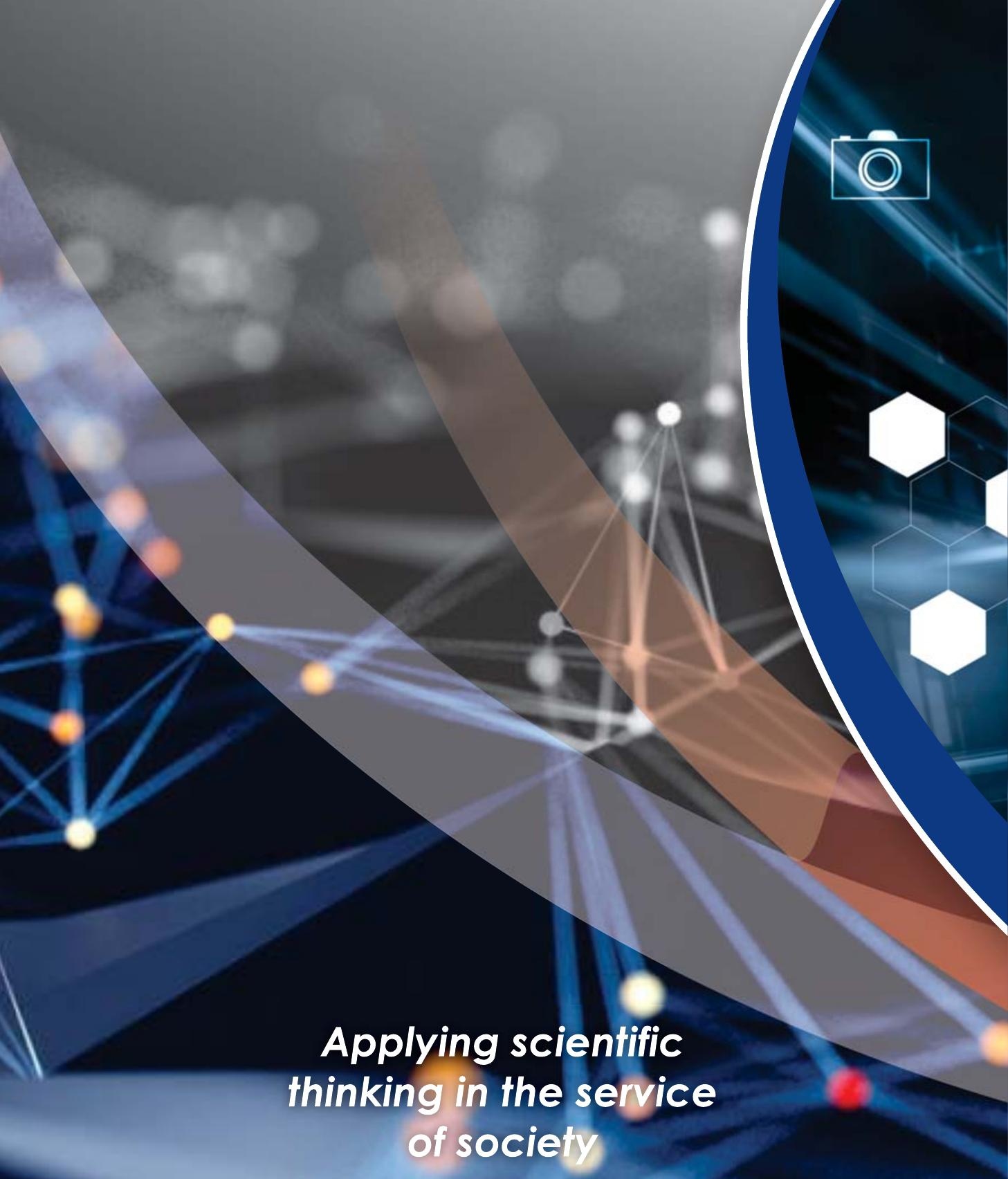

PO Box 72135, Lynnwood Ridge 0040, Pretoria, South Africa Tel: +27 123496600 | Fax: +27865769520 Email:admin@assaf.org.za 
2019

\section{Stakeholders Awareness Workshop on the 2019 White Paper on Science, Technology and Innovation (STI)}

Academy of Science of South Africa (ASSAf)

Academy of Science of South Africa (ASSAf)

Academy of Science of South Africa (ASSAf) (2019) Stakeholders Awareness Workshop on the 2019 White Paper on Science, Technology and Innovation (STI). DOI 10.17159/assaf.2019/0055 http://hdl.handle.net/20.500.11911/132

Downloaded from ASSAf Research Repository, Academy of Science of South Africa (ASSAf) 
2019

\section{Stakeholders Awareness Workshop on the 2019 White Paper on Science, Technology and Innovation (STI)}

\section{Academy of Science of South Africa (ASSAf)}

Academy of Science of South Africa (ASSAf) \& Department of Science and Innovation (DSI)

Academy of Science of South Africa (ASSAf) and Department of Science and Innovation (DSI) (2019) Stakeholders Awareness Workshop on the 2019 White Paper on Science, Technology and Innovation (STI). Available at: https://doi.org/10.17159/assaf.2019/0055 http://hdl.handle.net/20.500.11911/132 Downloaded from ASSAf Research Repository, Academy of Science of South Africa (ASSAf) 